Journal of Entrepreneur and Entrepreneurship, Vol. 7, No. 2, September 2018, 49-54

ISSN 2302-1802 print / ISSN 2580-9393 online

\title{
BUILDING TRUST IN FAMILY BUSINESS
}

\author{
Agustiono* \& Carlina Wijaya \\ School of Management and Business Ciputra University
}

\begin{abstract}
This research aims about how to build parent's trust at Super Rasa Jaya Company. This is a family company engaged in bakery industry. This research was a descriptive qualitative. For data collecting technique, this study used interview and observations method. The data were validated though data validity test. Data triangulation was carried out by interviewing 6 informants who worked as entrepreneurs. Four of them have become a successful leaders of the next generation for more than 5 years. Two others were the owners of Super Rasa Jaya Company. This study found the owner of Super Rasa Jaya Company (head of the generation) had not been able to have their trust on the performance of their future generations yet. To gain that trust, the future generations had to work very hard. They were also required to provide evidence about their work. The next generation had to be able to demonstrate high performance in running and organizing the company. They had to able to produce a variety of new products and improve the quality of production in order to get the trust from the heads of the previous generation.
\end{abstract}

Keywords: trust, reliability, openness, competence, compassion

$\mathrm{P}$ rice Waterhouse Cooper $(\mathrm{PwC})$ surveyed a family business in Indonesia in 2014 (CNN Indonesia, 2014). The result showed that more than 95 percent of companies in Indonesia are family businesses. Based on $\mathrm{PwC}$ records there are more than 40 thousand rich people or about 0.2 percent of the total population who run a family business in Indonesia, their total wealth reached Rp 134 trillion or accounted for about 25 percent of Indonesia's gross domestic product (GDP).

Carlock and Ward (in Erdem and Atsan, 2015) argue that the foundation of a company's planning and management system is a trust, a mutual respect and creates a trusting environment. According Perry in Christina et al. (2016) understanding of trust is one of the things that

\footnotetext{
*Corresponding Author.
}

e-mail: agustiono@ciputra.ac.id become a force in the family business. Family firms tend to be dynamic, and decision making within the company is quick and straightforward because it is based on trust as the basis for survival, and has close personal relationships with all employees by hitting management levels"

Survey conducted by Price Waterhouse Cooper (PwC) in CNN Indonesia (2014) produces information about sample profiles of family businesses in Indonesia. The age of family companies that can last more than 50 years is very little and very difficult to pass through 4 generations. Family inheritance plans for the next generation of more than $50 \%$ plan to pass ownership to the next generation but involve professionals. And about $25 \%$ will surrender ownership and management to the next generation.

Cooperation between the head of generations and the next generation is essential in 
running the company. The support and trustworthiness is the key to the company's development. The next generations must also show that they are trustworthy and dependable. A company that plans a succession requires these values in order to achieve success. So it is with Super Rasa Jaya Company that must have these values to achieve success.

Super Rasa Jaya Company is a company engaged in the food industry especially in the field of bakery. But Super Rasa Jaya Company can also serve as a distributor of snacks and drinks. Super Rasa Jaya Company established since 1999. Previously Super Rasa Jaya Company is a distributor agent of Ramayana Bakery Company. However, in 1999 the company finally decided to build a middle-class bakery downstairs. Currently Super Rasa Jaya Company is still run by the first generation. When viewed from the age of the company and the owner of the company, then this company will be downgraded the head of the next generation.

The successor generation of Super Rasa Jaya Company saw no trust given by the first generation in the development process of Super Rasa Jaya Company done by the next generation. Trust given to the next generation of generations, it will help the second generation easier in developing the company. Trust that will make the next generation feel comfortable and will also be more struggling and eager in helping the company development Super Rasa Jaya. The purpose of this research is to know the expectations of parents in building trust with the next generation in Family Business. Therefore, this research takes the tittle "The Process of Building Trust of Parents in Super Rasa Jaya Company”

\section{METHOD}

Data collection techniques used by researchers is by interview. Interview techniques used in this research are semi-structured interviews, ie finding problems more openly, in which the party interviewed is asked opinions, and ideas (Sugiyono in Kong, 2015). From the use of this technique is expected the author can dig deeper information from the sources.

The analytical method used is qualitative descriptive. According to Moleong (in Simanjuntak, 2014) the stages for analyzing data is to examine all available data from various sources, reduce the data and make categorization and then check the validity of the data and make the data interpretation. Application in this research is the author will review all the data received by the informants, then the author will make categorization to facilitate the author in reviewing the data. After that the author will check the validity of the data from informants. And finally the author will interpret the data that will answer the problem formulation in this study.

\section{RESULTS AND DISCUSSION}

After collecting various information from 6 resource persons selected according to criterion of informant, researcher find information how to build trust of parents which include reliability, openness, competence, and compassion.

\section{Reliability}

According to Mishra \& Mishra (in Tanu, 2015) one is said to be reliable when behaving in a balanced and consistent way and is responsible with what he has said and done. Reliability 
requires not only words but also action. The inconsistency between words and actions decreases trust which also implies one's commitment. Based on the results of interviews that have been done, it is known that in general the average head of the generation wants the nature of reliability is shown through concrete action to gain trust. From interviews with informants from various companies, they said that the attitude of reliability can be proven by the experience and the work done by the next generation. They should be able to prove responsibility for the work they do. According to Morgan and Hunt (in Adji and Semuel, 2014) conceptualize trust arises when a group has a belief that its partner has reliability and integrity.

In the company of Super Rasa Jaya, the head of the generation also as the informants. The head of the company Super Rasa Jaya's generation wants his future generation to prove his responsibility for his work. Currently future generation of Super Rasa Jaya Company has not been able to prove the responsibility and integrity of the company because it is still in the learning stage at the university level. Prospective current generation is only able to prove the nature of responsibility by completing his education well.

The way to build trust through the nature of reliability can be demonstrated by the actions of future generations through timely completion of lectures which is one way of showing responsibility for the parents. Then after completing his education, the next generation must be involved in the company Super Rasa Jaya. The successor generation of the Super Rasa Jaya Company must be able to deliver satisfactory results in accordance with the words or promises given. The next generation should continue to innovate with new quality products and try to market them. The successor generation must go directly into the company and assist mainly in the field of production after completing its educations.

\section{Openness}

Openness is a willingness to be honest and open in any relationship. Individuals will be more willing to believe a person's words if they believe that the person is telling the truth. The openness between heads of generations and future generations will encourage future generations to be more open (Mishra \& Mishra in Tanu, 2015). From interviews with informants from various companies, they said that the attitude of openness will be formed or occurs because of the attitude of parents to their children. Children will follow his parents' example and imitate what his parents did. Parents should be open with the child, so the child will do the same. At the Super Rasa Jaya Company, the head of the generation said that he exemplifies how to be honest and open. With that it is expected future generations imitate the positive actions undertaken by the head of the generation company Super Rasa Jaya. Currently the conditions in the corporate family Super Rasa Jaya almost can be said less in term of communication between the head often avoids the questions that the next generation asks. Therefore the need for more communication so that openness can happen.

How to build trust through the nature of openness can be shown by frequent communicating various things. The head of the generation must also more often communicate with 
the next generation and guide the next generation. Widodo (in Rahmawati, 2015) provides an explanation of the openness of one of the important attitudes that have relevance to how a person builds relationships or communicates with others. If future generations and heads of generations have an attitude of openness, it makes them more likely to have more realistic and well developed ways of thinking. This honesty and openness can be shown by the next generation by showing the behavior to the parents by doing positive things.

\section{Competence}

According to Miashra \& Mishra (in Tanu, 2015) direct experience with others is a more convincing way to demonstrate their competence beyond performance expectations and deliver results that support the goals and objectives of the company's strategy. From interviews with informants, they said that the competence of the next generation will take time to build before equalizing the head of the generation's competence. According to informants, the competencies possessed by future generations are formed by the parenting pattern of the head of his generation. If the next generation participate in doing the work, then the competencies expected by the parents will come true.

At Super Rasa Jaya's company, the head of the generation said that he wanted his next generation to master the inside knowledge of the company, especially in production field. Currently the next generation of Super Rasa Jaya Company cannot yet master the field of production. To build trust through the nature of competence can be demonstrated by future generations must learn all things concerned with the making of bread. The successor generation of Super Rasa Jaya Company must continue to develop its competence and always practice to increase its competence.

\section{Compassion}

Echols \& Shadily (in Ramadhani and Nurdibyanandaru, 2014) reveal that has sense of compassion means a sense of affection that is felt when people see suffering. According to Mishra \& Mishra (in Tanu, 2015) having a compassion towards others means having to want to set aside personal interests to be truly emphatic towards others.

From interviews with informants from various companies, they say that they will put priority on what is more important. They will put the company first if the company needs it more. They will not give hard to put their personal interests first. Each of these interests has its own priorities, so it is necessary to see which is more urgent and should be dealt with immediately.

In the company of Super Rasa Jaya, the head of the generation said that both are equally important. The next generation must be able to balance the personal interests and interests of the company. Currently the next generation of Super Rasa Jaya companies have much to learn to sort out which is more important. How to build trust through the nature of the compassion can be demonstrated with the next generation of Super Rasa Jaya Company should be able to analyze each problem in order to sort out what should be prioritized.

\section{CONCLUSIONS}

The successor generation of the Super Rasa Jaya Company must be able to deliver satisfac- 
tory results in accordance with the words or promises given. The next generation should continue to innovate with new quality products and try to market them. The successor generation must go directly into the company and assist mainly in the field of production after completing its education.

The successor generation must always be honest and communicate more with the head of the generation about daily life and work that has been done to show evidence of what the next generation has done to the company. The head of the generation must also more often communicate with the next generation and guide the next generation. This honesty and openness can be shown by the next generation by showing the behavior to the parents by doing positive things.

With the help and support of the head of the generation, the ability or competence will continue to grow. The successor generation of Super Rasa Jaya Company must continue to develop its competence and always practice to increase its competence.

The successor generation of Super Rasa Jaya Company should be able to analyze every problem in order to sort out what should be prioritized.

The researcher suggested that Super Rasa Jaya companies pay attention to each other between the next generation of the company and the head of the generation. With the attitude of mutual understanding and care, it will build good relationship and cooperation between the next generation, and it will have a good impact on the company. Should the next generation show honesty, responsibility, competent and able to distinguish which interests should be prioritize, trust from the head of the generation will grow
Limitation of this research is this research cannot be generalized by other research. This study discusses how to build the trust of parents in a family company located in Lombok Island. This study uses quantitative methods.

\section{REFERENCES}

Adji, J. 2014. Pengaruh Satisfaction dan Trust Terhadap Minat Pembelian di Starbucks the Square Surabaya. Jurnal Strategi Pemasarpan, 2(1), 1-10.

Barrett, M. 2014. Theories to define and understand family firms.

Christina, C., Saputra, I.T.T., \& Tjandrawibawa, P. 2016. Cognitive Trust di Dalam Bisnis Keluarga (Studi Kasus pada PT Dharma Samudera Fishing Industries, Tbk).

CNN Indonesia. 2014. Survei PwC: 95 Persen Perusahaan di Indonesia adalah bisnis keluarga. Retrieved from http://www.cnnindonesia.com/ekonomi/2014120210035692-15176/pwc-95-persen-perusahaanindonesia-adalah-bisnis-keluarga/.

Erdem, F., \& Atsan, N. 2015. Trust Based Relationships between Family Members and Long-Term Employees of FamilyOwned SMEs. International Business Research, 8(4), 223-232.

Kong, W. 2015. Analisis Implementasi Etika Korporasi di PT X. Agora, 3(2), 52-59.

Price Waterhouse Cooper (PWC). 2014. Survey Bisnis Keluarga 2014. Retrieved from http:/ /www.pwc.com/id/en/publications/assets/ indonesia-report-familybusiness-survey2014.pdf.

Ramadhani, F. \& Nurdibyanandaru, D. 2014. Pengaruh Self-Compassion terhadap Kompetensi Emosi Remaja Akhir. Jurnal Psikologi Klinis dan Kesehatan Mental, 3(03), 121. 
Agustiono \& Carlina Wijaya / Buliding Trust Family Business /

JEE, Vol. 7, No. 2, September 2018, pp 49-54

Simanjuntak, P.A. 2014. Analisa Performa Pasca Suksesi pada Perusahaan Keluarga dalam Bidang Produksi ASBES. Agora, 2(2), 1319-1328.
Tanu, N. 2015. Pengaruh Ikatan Keluarga Terhadap Keberhasilan Usaha Keluarga (Studi Kasus Toko Jam Jalan Surabaya Medan dan Sekitarnya). 